\title{
Pedagogic Challenges Involved in the Teaching of Citizenship in Public Secondary Schools in the South West Region of Cameroon
}

\author{
Tamuh Divine Chenwi \\ B. A, M.Ed, Phd in View, University of Buea, South West Region, Cameroon
}

\begin{abstract}
The purpose of this research was to find out some pedagogic challenges involved in the teaching of Citizenship in Government Secondary Schools in the South West Region of Cameroon. This paper stated one objective, and was carried out using the same as the research question which was later translated to research hypothesis to ascertain the finding of the study. The survey research design was used, and the sample was selected using the simple random sampling technique. The sample consisted of 150 Teachers in five out of the six Divisions of the South West Region of Cameroon. The questionnaire was the main instrument used in the study to collect data. The data was analyzed using, the descriptive and inferential statistics and the obtained showed that teachers have been trained in their main subjects, but not Citizenship.
\end{abstract}

Key Words: PEDAGOGY, CHALLENGES, TEACHING, CITIZENSHIP, PUBLIC, SECONDARY, SCHOOLS

\section{INTRODUCTION}

Education is a national priority in Cameroon as such it is a vital element in national and international development Proper education therefore assures a nation of a skilled labour force, effective leadership and good and loyal citizens. In May 1995, a National Forum on Education was organized in Yaounde. Its purpose was to discuss or deliberate on new perspectives on education in Cameroon. The results of the forum were enacted as the law on education that is law No 98/004 of $14^{\text {th }}$ April 1998 to lay down guidelines for education in Cameroon. In view of this, policy makers proposed and reviewed subjects and syllabuses, created new subjects and broad fields. Citizenship is one of the subjects whose syllabus was reviewed in April 2011 by the Cameroon General
Certificate of Examinations Board (G.C.E Board) and also a broad field created. Keer. (1999). indicates that as part of an on-going review of the national curriculum, Citizenship Education was also examined and it was realized that the subject was so important both for the schools and the nation, the syllabus content is a broad field. Allan, and Francis. (2009), describe broad fields as an inter-disciplinary design that attempts to integrate content that fit together logically, for example, the content of Geography, Economics, History, Political Science, Anthropology, Sociology, Philosophy and Religion which are fused into social studies. Nyanyoh (2010), remarks that the syllabus for Citizenship, has been so extensively broadened to include all areas of human relationships, political, social, economic, traditional, moral and even the spiritual well being of the Cameroonian citizen. Citizenship therefore has been tailored to meet the aspirations of policy makers as well as to take into consideration the prevailing socio- economic, political and cultural atmosphere of the country in line with global trends. Tazifor. (2006) sees Citizenship as the training of youths for intellectual, civic and moral development aiming at a smooth integration into the society. On her part, Nyanyoh (2010), states that, Citizenship aims at informing, clarifying, inculcating, promoting and deepening in every Cameroonian and very specially the youths of Cameroon the essential values of nationhood and good citizenship. Though this subject is seen as being very significant in the Cameroonian context today, it should be noted that no teacher training college is yet training instructors to teach it. As such, the Ministry of Secondary Education (MINESEC), has therefore assigned all social science teachers that is teachers of History, Geography, Economics, Philosophy and Religious Studies with the responsibility to teach the subject. This researcher sees some possible challenges that 
these teachers will face in teaching it, especially as it is not in their subject discipline and because the content is drawn from different subject specialties.

In view of this, this researcher intends to research on the pedagogic challenges teachers face in the teaching of Citizenship in secondary grammar schools in the South West Region of Cameroon. The focus will be on the challenges involved with the quality of the teachers and their attitudes towards the subject, the use of instructional materials, assessment strategies, as well as teaching methods.

\section{Objectives of the study}

To bring out the problem of the quality of teachers who teach Citizenship

Research Question

\section{Hypothesis}

Null Hypothesis (Hoi)

The quality of Citizenship teachers is not appropriate to teach the subject. Alternative Hypothesis ( $\mathrm{Hal}$ )

The quality of Citizenship teachers is appropriate to teach the subject.

\section{STATEMENT OF THE PROBLEM}

The introduction of Citizenship Education in the secondary school curriculum meant an end to Civics which hitherto dealt with the rights and duties of citizens. Civics was taught mostly by History teachers and some Geography teachers. But with the new orientations in education, Citizenship took its place. Now all social science teachers i.e. History, Geography, Economics, Religion and Philosophy teachers have to teach Citizenship as stipulated in ministerial secular letter No 31/06/MJNESEC/IGE/IGP-SH of 12 June 2006 concerning the creation of the council for the teaching of Citizenship. Though the teaching of the subject has been entrusted in the hands of social science teachers, they have not been trained to teach it. Also, no Teacher Training College is currently training instructors in this discipline. These teachers are therefore bound to apply the methodology and experiences in teaching their trained subjects to teaching Citizenship which cannot be very effective since it is a broad field cutting across many topics and subject disciplines. The teacher is seen as the guarantor of quality education. For this to be achieved, he should be trained to offer the desired products especially with the much talk of falling standards of our educational system and the high level of moral decadence in our society. Since instructors of this subject are not experts, there is the likelihood that they may encounter some difficulties as they teach this 'pretty new subject'.

It is therefore on this premise that the researcher seeks to investigate the pedagogic challenges faced by teachers of Citizenship in the South West Region precisely in Government Secondary Grammar Schools. Thus when these challenges are identified and remedies given, it is hoped that the objectives of teachers and the aims of the subject and policy makers, would have been achieved.

\section{BACK GROUND TO THE STUDY}

Historically, Citizenship got its foundation from ancient Greek times in small-scale organic communities of the polis. Citizenship was concerned with the daily life in the polis where everybody was very active. To show citizenship, Aristotle was quoted at saying "to take no part in the running of the community's affairs is to be either a beast or a god." Thus members had obligations to the community and not rights given them by it.

Citizenship at this time as well as in mediaval cities that practiced polis citizenship was exclusive and inequality of status was widely accepted. In the Roman Empire, citizenship was expanded to the entire empire so as to legitimize Roman rule over conquered areas. Thus the concept of Citizenship has evolved over centuries in different dimensions in different areas and has had different definitions. Citizenship is the state of being a citizen of a particular social, political, national, or human resource community.

Virginia (1999) equates Citizenship as connoting "a bundle of rights-primarify, porrtfcai participation in the life of the community, the right to vote and the right to receive certain protection from the community as well as Obligations.

Tazifor (2006) describes it as the training of youths for intellectual, civic and moral development aiming at the smooth integration into society bearing in mind the prevailing socio-cultural, political and moral factors.

Recently, citizenship has moved from communities or nations and has taken a wider dimension. It is best 
identified with being a member of a particular nation. To some extent certain entities cross national boundaries such as trade organizations, Non Governmental Organizations and multinational corporations have made the notion of citizenship to go international Thus members of these bodies have either acquired citizenship where they are or it has simply been conferred on them by their host governments. Generally though, citizenship is obtained through blood (ancestry or etihnicity), through birth (local nativity), through marriage and naturalization. There isalso honorary citizenship which is awarded to someone irrespective of his/her area of origin.

Citizenship Education was brought about from the notion of active citizenship. This is. a philosophy that citizens should work towards the improvement of their community through economic participation, public volunteer work etc

Others see it as learning activities, curriculum and/or educational programs at any level, concerned with rights and responsibilities of citizenship -with the purpose to promote knowledge, skills, and attitudes conducive to effective participation in civic life.

Derek (1998) indicates that the concept of citizenship has developed over the course of two and a half millennia. It dealt with an individual acquiring a status of right and independence in a community or nation through birth or naturalization. It is not surprising therefore that constant accretions overtime have rendered it extremely complex today. From it's origin in Greek City States, the concept has had variations when compared with most modern states. Improvements were made during the period of Renaissance, In these societies, the status of citizen was not only restricted in various ways, but women were excluded.

From the late seventeenth century to the early twentieth century, Britain, France, and USA led the way in defining what the rights of citizens should be in legal and political terms. This was seen in the American Bill of Rights and in a series of Acts of Parliament in Britain which was required from 1832 to 1969 to extend voting rights to all social classes, women and people between 18 and 21 .

It is realized that Citizenship Education had gone beyond acquiring status as a citizen as times evolved, but emphasizes on the importance of moral and civic education in the training of the citizens. This is the case of Cameroon as stated in law No $98 / 004$ of $14^{\text {th }}$ April 1998, article 4 on the orientation of education in Cameroon.

Tambo, (2003) states that by 2003, formal education or western type schools in Cameroon was one hundred and fifty nine years old. It was introduced by the missionaries from Jamaica who was sponsored by the Baptist Missionary Society based in London. Reverend Joseph Merrick, who led the religious order, opened the first school in Bimbia in 1844. As a man of God, it is without doubt that moral education which was and is an aspect of citizenship education was not left out even though their focus was on Religion. Thus as education later evolved through the pre colonial, colonial and post colonial era, moral and civic education has simply changed from one form or from one name to another.

Nyanyoh (2010) stipulates that Civics as a subject in the school curriculum, from which Citizenship later got its name, is as old as the English subsystem of education in Cameroon. She further indicates that Circular N0.53/D/64/MINEDUC/IGP/IPN-HG of 15 Nov, 1990, changed the name from Civics to Citizenship. However, the proper status or place of this subject was earlier recognized in the Francophone sub-system of education. It is recently that the English sub-system is effectively implementing this decision. Thus the evolution of the subject has recently been an issue of national concern. Besides, the status of citizens in Cameroon has been regarded to be very important as seen in the constitutional evolutions that the country has witnessed for example, 1960, 1961, 1972, 1985 and 1996 constitutions. It will be observed that, from the 1998 law on education, Civics was finally coffined with Citizenship as the successor. Following the Citizenship syllabus review of the G.C.E Board, the title was proposed as Citizenship Education. This title it should be noted is what is being used in most countries today like France, England and Honduras. As part of the implementation, subsequent decisions have been signed for example, circular No: 30/05/MINESEC/IGE/IGP/SH of $12^{\text {th }}$ April 2005, establishing the Citizenship syllabus for general secondary education. The evolution then continued in classrooms, seminars and workshops and so on. Generally, it should be noted that the historical background of this subject is varied. Individual 
communities or societies have different developments and dimensions as far as Citizenship is concerned. It also varies with nations as well as their educational developments and policies.

Teachers and learners in the past have always had difficulties in the teaching and learning process. These problems arise in specific subjects. As such, many schools of thoughts had emerged to bring out the correlation between the problems or difficulties faced and the process of teaching and learning. Some theories that are relevant to this paper include.

1. Constructivist theory

2. Conceptual change theory

3. Cognitive theory of multimedia learning

4. Social constructivism

5. Expectancy theory.

\section{Constructivist Theory}

Constructivism is a set of theories made up of cognitive constructivism and social constructivism. It is observed that cognitive constructivism which is about how the individual learner understands things, in terms of developmental stages and learning styles. Social constructivism emphasizes how meanings and understanding grow out of social encounters. These theories of Piaget and Vygotsky will apply effectively here as the teachers and learners of Citizenship are building on material which they had studied as they developed and also they interact with their environment which is where the syllabus of Citizenship is drawn.

\section{Conceptual Change Theory}

Poßner, Strike, Hewson and Gertzog (1982) define conceptual change as learning that changes an existing conception that is, belief, idea or way of thinking. It is supposed that teachers have a negative attitude towards Citizenship especially because they have not been trained to teach it, as well as the fact that it is not yet a GCE subject, etc. In this theory, existing conception is fundamentally changed or even replaced, and becomes the conceptual framework that both students and teachers are to use to solve problems, explain phenomena, and function in their world Davis. (2001)

\section{Cognitive Theory of Multimedia Learning}

This theory shows learners in relation to multimedia facilities to enhance their learning. It emphasizes that students learning given multimedia with animation and narration consistently did better on transfer questions than those who learn from animation and text-based materials. Thus multimedia rather than mono-media instruction is better. This theory will adequately apply to this study because subject content material on Citizenship in Cameroon is still very limited or better still spread in different subject discipline. As such different medias need to be consulted or used for the effective instruction of Citizenship.

\section{Social Constructivism}

The theory focuses on learners and describes how the socio cultural background of learners helps them to create, discover and attain academic goals. The society and schools therefore play significant roles in child development and achievement.

\section{Expectancy Theory}

This theory deals with how an individual's behaviour can be motivated leading to work related outcomes or rewards that they value. The theory focuses on three main variables that is expectancy, instrumentality and valence which are obtained from the relation between efforts, performance and rewards or outcomes.

Conceptually, citizenship goes beyond individuals in the society and deals with their wholesome participation and mil integration into the society. The subject Citizenship from creation in Cameroon is viewed to have so much contribution to youths, the community and nation as a whole. It thus prepares and ensures a smooth integration of youths in society by developing civic and moral attitudes in them as well as building a patriotic spirit amongst citizens.

INC A report of 16 countries indicates that the context of Citizenship Education varies from one country to the other leading to variations in definitions and approaches. Thus what works in one context dose not necessarily apply in the other? In this like, a careful adaptation rather than wholesale adoption should be the watch word .The report identified a number of contextual factors which influence the definitions and approaches to Citizenship Education like; historical tradition, geographical position, socio-political structure, economic system and global trends.

Contextually in Cameroon, Citizenship Education replaced Civics which dealt with rights and duties of citizens as well as current events. This means that Civics has been revised or reviewed into Citizenship Education. All these to make the subject to suit the present realities of globalization and develop 
competencies or life skills in learners. This pretty new subject therefore was not only for intellectual purposes but also to ensure a complete integration into society.

Another context which necessitated the birth of the subject is the high rate of moral decadence in the society-embezzlement, corruption and bribery, lies telling, untimely deaths especially of youths, juvenile delinquency, internet theft 'scamming', prostitution etc. All these make the community not worth living. These vices only produce a decayed community in which competence, meritocracy, expertise do not have a place. In this context, the subject being taught in all schools will help shape the minds and hearts of youths and adults towards a country where efforts and positive feelings are rewarded both by God and man or society. This makes the subject indispensable in the Cameroonian context where these vices exist.

Another context that provoked the putting into place of Citizenship Education is the prevailing socioeconomic and political atmosphere that reigned in Cameroon in the last two decades. During this period, the country witnessed some events or upheavals in its national life which warranted a subject like this to change the mindset of the population. Some of these events included Ghost Towns operations, which came with multipartism, post election violence, a series of strikes especially the February 200S uprisings which brought untold hardship on Cameroonians and civil demonstrations. In all these activities, the youths are seen to have been actively involved. They were considered to have been manipulated by adults or politicians. Thus the destructions and lootings witnessed with such events are attributed to youths. In this context therefore, the inception of Citizenship Education is seen as a means of preparing youths towards positive goals and attitudes towards the nation Cameroon. To build a sense of direction and purpose, to make them see violence and destruction as bad, to embark on nation building and be patriotic. With this, it is hoped that they would cautiously refuse to be partakers in any event or activity against the state .In this context; the subject would develop a high spirit of patriotism in the learners, teachers and consequently society as a whole which ensures a peaceful coexistence.

Culturally, the context of Citizenship in this study would be seen as one that makes youths to identify themselves with their various villages, tribes and nations. Thus youths will see value and virtue in all that is Cameroon and not depend on or look at the Diaspora as a place filled with milk and honey. Cultural diversity of the nation should be appreciated by all youths irrespective of their region, tribe or village. Thus the over 250 ethnic groups would not be seen as a problem, but as a melting pot which brings unity and strength thereby promoting national integration. So each citizen has the right to live, and work in any part of the territory without fear or favouror discrimination.

Biya, (1989) talked about rigour and moralization upon his ascension to the Supreme Magistracy of the Country Cameroon. As head of state it became a policy implemented by his heads of governments. This culminated in the famous "operation Sparrow Hawk", whereby corrupt government officials are uplifted of their functions and detained. Thus to promote rigour and moralization and to stop embezzlement of state funds and mismanagement of state resources, Citizenship Education is seen as the best thing in our context that would ensure a transparent society void of these ills.

Global events also made the need for Citizenship Education to see the light of day in Cameroon. Cameroon is not an island and thus, participates actively in international issues and organizations which deal with issues like the environment, rights, education, elections, etc. Also the country has also ratified agreements and conventions with international bodies like UNESCO, UNICEF, etc. With all these the standards of activities and events must conform to the international standards and regulations. The values of all these is built in Citizenship Education.

The subject Citizenship Education could be considered to have had its roots from the smooth, peaceful and voluntary transfer of power from President AmadouAhidjoto President Paul Biya on 6 November 1982 Fanso (1989) states that "Biya declared that he would inject the policies of his predecessor with rigor, integrity and moralization." His New Deal administration would reject the irregularities, lateness, laxity, wastefulness, and irresponsibilities in the conduct of public affairs and would condemn misappropriation of public or private funds, corruption, fraud or illegal acquisition of wealth and moral depravity. The presidents" pledges and declarations as seen called for a Cameroon nation that is void of vices. A society whereby transparency and duty consciousness was going to be the watchword. 
These lofty ideas meant that both the governors and the governed were to put their hands on deck for this to be achieved. In this context Civics was reviewed and changed to Citizenship so that through Education all Cameroonians will see the vision of the head of state and promote it for a better Cameroon. It should be noted that these declarations by H.E Paul Biya constitute some of the topics that are being studied in Citizenship today. Thus the policy if rigour and moralization was established to form a new order in the political philosophy of Cameroon with its objective to introduce good governance in the administrative set up of Cameroon. Citizenship Education is therefore seen as one means by which these can be achieved especially since the youths are described as the leaders of tomorrow.

According to Apum (2010), one of the greatest threats to Cameroon's progress today is the moral crisis that has impeded every sphere of the society. From the political to the civic and from the religious to the cultural spheres corruption has deeply implanted itself This is observed when members of the Executive especially ministers have been accused time and again for embezzlement of state funds, public contracts are awarded not based on competence, members of the Judiciary are said to be commercializing justice, the media i.e. some journalists are praise singers and run behind individuals or institutions to get money so as to forfeit information, entrance examinations are not totally considered to be based on academic achievements but on bribery, school administrators take bribe in exchange for admissions, teachers who aught to uphold morality in the society, are drowned in this pool of corruption. They sell marks for sex. The military i.e. police, Gendarmes, etc are not corruption free. The private sectors as well as religious institutions also have aspects of moral decadence or waywardness. This moral crisis is best solved by Citizenship Education.

Even though the government put in several policies to tight corruption and other ills like creation of an Anticorruption unit, these vices seem to be on a steady increase. In 1998 and 1999, Transparency International, an international Non Governmental Organization ranked Cameroon as the world's most corrupt country. Over 10 years after that, there is still the much talk on corruption. Thus this fight should not only be that of the executive, Judiciary and legislative arms of government. The citizens, who are given $a$ special place in the Cameroon constitution as well as education considered as one of the priorities of the state, should and have been given the consideration. In this context therefore, the teaching and learning of Citizenship Education targets youths (citizens) who form a greater part of the population of the country. It is also hoped that their understanding of this subject would have a multiplier effect in the society. Thus when youths are educated to develop fear and love or patriotic feelings for their country, all the ills and vices plaguing the country would be considered eradicated. It is in this context that Citizenship Education is created to moralize Cameroonian citizens and ensure good governance.

Current urban development has led to so many challenges in the cities. Migration and mobility reduce the cohesion within many urban societies; cities have become complex entities in which ethnic, social and cultural segregated communities have developed. Also, cities develop the breeding ground for new, mostly cultural expression of civic participation in order to create new forms of public spheres or civic involvement. The city mirrors social challenges and becomes a lab of cultural and social developments in which questions of economy and work of social belonging and recognition, of cultural self-perception and external perception, of political participation and justice are renegotiated NECE (2010). All these are issues that were evident in Civics and now Citizenship Education has been tailored to meet up with these challenges.

The policy context within which Citizenship Education is approached in schools in England in 2007 resulted from changes on the curriculum delivery, whole school approaches and their links to the wider communities. To contextualize this, programmes like; the every child matters which sought to ensure that children are healthy, stay safe, enjoy and achieve, make a positive contribution and achieve economic well-being etc. were introduced. Others include; the personalized learning 2004, the 5 years strategy plan and national strategies programme 2006 and working together 2004, all formed the policy context within which Citizenship Education was approached in England 2007.

From the forgoing, it is observed that in this context, Citizenship Education is considered a timely intervention in this era of globalization and moral decadence. This would also encourage the need for a study like this one to be carried out. Consequently, 
teachers and learners have to surmount the difficulties in the teaching and learning of the subject, so as to ensure that the goals of education and aims of the subject should be realized or achieved.

Patricia and Thomas (1998) states that the quality of student learning is directly - although not exclusively - related to the quality of classroom teaching. Therefore, the first and most promising way to improve learning is to improve teaching. So for quality feedback to be achieved, quality teachers are needed which of course is a problem which citizenship education is currently facing.

Teachers of Citizenship Education are either specialists or generalists depending on the country and level of education. "Specialist teachers" in the context of Citizenship Education, are specialists either in a number of subjects closely related and including Citizenship Education or in a closely related subject. They are not specialists in Citizenship Education parse but may teach it alongside their responsibilities as a teacher of social sciences. This, however, raises the issue of the extent to which these teachers prioritize their Citizenship Education teaching over their other teaching duties. Also, these specialists' Citizenship Education teachers have a background in social science subjects through qualifications and experience, and this may determine where their interest or loyalties lie.

Armstrong \& Savage (1994), describe professional development as a "career long obligation". This is so because, when a teacher undertakes a training course, he acquires an insight into the psychological needs of the students. Further, they opine that with a sound professional training, backed by certificates, there will be a corresponding high quality in the use of educational resources in the class.

Bame, (2007) sees professionalism as a commitment by teachers which ends in quality teaching and learning. The teacher looks at the learners and education as a priority. As such, they enthusiastically accept the challenges of teaching without complain about the learners, the classroom processes and practices. He further states that quality should characterize teachers' interaction with students, administrators and colleagues, parents and the public. With all these, learners and colleagues would be motivated to put forth similar efforts.
Tsafact(2003). Holds that as teachers undergo more training, it develops their skills and confers the status of professionalism on them. This exercise culminates into a logical high level of responsibility and output as they exercise out their profession.

In most countries as indicated by INCA report 1999 there is no specific initial and in-service training of teachers for citizenship education rather man\}' of them are trained butin closely related subject areas. This is also the case of Cameroon. All these affect the quality of citizenship education teachers as well as the quality of the instruction. Thus an inadequacy in the preparation of teachers exists not only in the lack of content knowledge but also in their inability to use a range of teaching and learning approaches.

Felisa, and Judith. (1999) think it is important to pay attention to the needs of teachers if a successful citizenship education is to be achieved in the future. They recommend valuable professional development tools and well designed training experiences and even pre service training will be pre conditions for success. Teachers' learning can be in corporate through educational programs, materials, follow-up support, opportunities for advancement and recognition. All these would assure quality teaching.

To motivate and prepare teachers to offer citizenship education program that reflect the qualities needed, pre service and in service training programs should be organized whereby teachers should be seen as beneficiaries and advocates for such programs rather than transmission vehicles (OAS 1998, p. 41) organization of the American study of Education reform. For quality teaching, these training should be systematically integrated with follow-up support and opportunities for sharing.

Magda D., Marie C. and Annika E. (2005) declare that education has an important role in preparing future citizens at all levels of the education system. And so, higher institutions are therefore charged with providing quality teachers who will adapt and develop new approaches that will enable them to engage reflectively and critically with the profound changes within society.

The OECD (1997) suggests that teachers are the final and most important link in the delivery of education as well as the interface through which the objectives of schools and education systems are mediated. Darling- 
Hammond (2000, 1999) also acknowledges this area of concern and further identifies the critical importance of teaching quality in education provision to meet the challenges presented in today's society.

Teachers are seen as the key resource for citizenship education where they are involved in the coordination, planning and delivery of citizenship education in schools. It considers the professional background and the level of input of the staff involved as well as the training needs and the degree and quality of continuous professional development available to teachers.

One of the main challenges to citizenship education is that of training. A majority of its teachers have not been trained either internally (school) or externally; some however received informal training.

To guarantee quality in the instruction of citizenship education the fifth annual report 2006 identify other training providers which include:

$>$ Citizenship organization

$>$ Commercial organizations

$>$ Examination boards

$>$ Universities

$>$ Charities

$>$ The learning skills development (L.S.D.A).

When teachers receive training, they perceive it to be very useful especially if it forms part of their professional qualification.

Geoff, (2004) in bringing out the quality of a teacher in the teaching learning process, puts them into two categories that is instructors and facilitators. The instructor is described as one who plans and directs all students' activities so as to transmit a body of knowledge and skills. The teachers are also in charge of assessing and evaluating the students work. This approach leads to learner dependency on teacher and they are unable to solve problems unaided. On the other hand, a facilitators' approach is one in which the teacher helps learners to gain control, plan, carryout and evaluate their learning. The teacher acts as a guide. This makes learner to be much more committed and interested in their work since it is designed by them.

From the foregoing, Geoff and many effective teachers think a good teacher is the one who uses the facilitator approach. However, quality teaching in practice would be achieved if a continuum between "instructor" and "facilitator" approach is applied by teachers. Thus teachers should move back and forth along this continuum as the situation demands.

\section{METHODOLOGY}

\section{Research Design:}

The research design selected for this paper consists of two components -the method and purpose components. By method, the study is a survey of selected schools in the South West Region. By purpose, this research is aimed at evaluating the current state of affairs in the teaching of Citizenship in the South West Region. This paper is therefore an Evaluation Survey of the teaching of Citizenship.

The research uses the survey research design whereby data is collected using a questionnaire or interview guide. In this study, questionnaires are used in the collection of data as well as an interview guide. The use of this design necessitates a study of a representative sample, which will allow the researcher to make inferences or generalizations to the population under study.

\section{The Population of the Study}

This study was carried out in Public Secondary Grammar Schools in five Divisions of the South West Region, namely: Fako, Kupe-Muanenguba, Manyu, Meme and Ndian Divisions.

The target population of this study, therefore, is made up of all the Social Science teachers in Government Secondary Grammar Schools in the South West Region.

According to official records from the Regional Delegation of Secondary Education for the South West for the 2010/2011 beginning of year report, there are 3460 teachers in the Region, 2535 of whom are in Government Grammar Schools. Out of this number, 768 are Social Science teachers. The target population for this study, therefore, consists of the 768 Social

Science teachers from both rural and urban Public Secondary Grammar Schools. The accessible population consists of the Social Science teachers who teach Citizenship Education. 
International Journal of Trend in Scientific Research and Development (IJTSRD) ISSN: 2456-6470

Distribution of the Target Population of the Study

\begin{tabular}{|c|c|c|c|c|c|}
\hline SIN & Division & No. of Schools & $\begin{array}{c}\text { No. of Public } \\
\text { School teachers }\end{array}$ & $\begin{array}{c}\text { No. of Social } \\
\text { Science teachers }\end{array}$ & $\%$ \\
\hline 1 & Eako & 25 & 1245 & 387 & $31.1 \%$ \\
\hline 2 & Kupe - M & 20 & 210 & 44 & $21.0 \%$ \\
\hline 3 & Lebialem & 19 & 201 & 57 & $28.4 \%$ \\
\hline 4 & Manyu & 30 & 221 & 85 & $38.5 \%$ \\
\hline 5 & Meme & 37 & 509 & 155 & $30.5 \%$ \\
\hline 6 & Ndian & 23 & 149 & 40 & $26.9 \%$ \\
\hline Total & 06 & 154 & 2535 & 768 & $30.3 \%$ \\
\hline
\end{tabular}

Source: Service of School Maps, Guidance and Counseling and Co-Curricular Activities, South West Regional Delegation of Secondary Education, 2010/2011 Beginning-of-Year Report.

\subsection{Sample and Sampling Technique}

According to Fraenkel and Norman (2000), a sample is a portion of the population that is studied with the intention of generalizing the results of the studies from it onto the entire population. It is also a specified number of items, objects or persons, drawn from the target population through the sampling process. The sample for this study is made up of 150 teachers selected using the multistage random sampling technique from five Divisions of the Region. Schools were sampled randomly by tagging their names into containers according to the Divisions. A tag was drawn from each of the containers and the process repeated until the proportionately required number of schools from each Division was obtained. The result is shown on Table 3.2 below.

Table 3.2: Distribution of the Sample of Schools and Social Science teachers per Division

\begin{tabular}{|c|c|c|c|c|}
\hline No & Divisions & No. of schools & No. of schools selected & Proportion Selected \\
\hline 1 & Fako & 25 & 06 & $16.2 \%$ \\
\hline 2 & Kupe- Muanenguba & 20 & 04 & $13.0 \%$ \\
\hline 3 & Manyu & 30 eve & Opme 05 & $19.5 \%$ \\
\hline 4 & Meme & 37 & 06 & $24.0 \%$ \\
\hline 5 & Ndian & 23 & 04 & $14.9 \%$ \\
\hline & Total & 154 & 25 & $16.2 \%$ \\
\hline
\end{tabular}

The next stage consisted of the selection of teachers from the sampled schools. This was done simply by using all the Social Science teachers because of their small population. Hence the sample used is made up of all the Social Science teachers who effectively teach Citizenship in the sampled schools from form 1-7 distributed as shown on table below.

Table: Distribution of Sample Size by School

\begin{tabular}{|c|c|c|c|}
\hline Divisions & Name of schools & Accessible population & Sample of teachers \\
\hline \multirow[t]{6}{*}{ Fako } & G.B.H.S Limbe & 27 & 10 \\
\hline & G.H.S Limbe & 23 & 08 \\
\hline & G.S.S Bwiyuku & 09 & 07 \\
\hline & G.S.S Bolifamba & 08 & 06 \\
\hline & G.S.S Motombolombo & 07 & 06 \\
\hline & G.B.H.S Muea & 18 & 13 \\
\hline Kupe & G.B.H.S Tombel & 10 & 05 \\
\hline \multirow[t]{3}{*}{ Muanenguba } & G.H.S Ebonji & 06 & 03 \\
\hline & G.H.S Nguti & 07 & 03 \\
\hline & G.S.S Manyemen & 03 & 02 \\
\hline
\end{tabular}


International Journal of Trend in Scientific Research and Development (IJTSRD) ISSN: 2456-6470

\begin{tabular}{|l|l|c|c|}
\hline Manyu & G.H.SBachuoNtai & 06 & 06 \\
\hline & G.S.S Mbinjong & 02 & 02 \\
\hline & G.B.H.S Mamfe & 10 & 09 \\
\hline & G.H.S Mamfe & 08 & 08 \\
\hline & G.H.S Tinto & 06 & 06 \\
\hline Meme & C.C.A.S Kumba & 26 & 08 \\
\hline & G.S.S Malende & 03 & 03 \\
\hline & G.B.H.S Kumba & 17 & 07 \\
\hline & G.S.S Nkamlikum & 09 & 06 \\
\hline & G.S.S Kumba- Mbeng & 09 & 05 \\
\hline Ndian & G.B.H.S Mbonge & 12 & 10 \\
\hline & G.H.S EkondoTiti & 07 & 05 \\
\hline & G.B.H.S. Mundemba & 10 & 06 \\
\hline & G.S.S Bulu Camp & 03 & 03 \\
\hline Total & G.S.S BafakaBalue & 03 & 03 \\
\hline & 25 & 249 & 150 \\
\hline
\end{tabular}

\section{Instrument for Data Collection}

Data was collected using a questionnaire constructed for teachers of Citizenship, constructed in conformity with the objectives of this study. The questionnaire was accompanied by a cover letter stating the paper topic, explaining the purpose of the study and how the result would be used. It also appealed to the respondents to complete the questionnaire, stating clearly that the confidentiality of their opinions would be strictly respected.

The questionnaire which consists of 24 items was divided into five sections as follows:

1. Section A contains 7 items that dealt with personal or demographic information. It addressed such issues like respondents' names (optional), professional and academic qualifications, longevity in service, name of school, the classes taught and the respondents' gender.

2. Section B is made up of 7 items addresses issues related to the quality of Citizenship teachers.

The questionnaire is basically close ended with five likert - type response options of Strongly Agree (SA), Agree (A), Disagree (D), Strongly Disagree (SD) and Undecided (U). The respondents were expected to tick the response option that best describes their opinions of the issues raised by each item. Also, some of the items were open-ended, requiring the respondents to freely express their own opinions.

Interviews were also conducted, basically to get statistical information and to collaborate (triangulate) the respondents' responses.

\section{Administration of Research Instrument}

The distribution and collection of the questionnaire was done by friends, teachers and the researcher in person. The sampled schools were visited and the administration consulted. In the cases where the questionnaire was administered by the researcher, members of the school administration and teachers of Citizenship welcomed and showed him round the school and helped out in the administration of the questionnaires to concerned teachers. In other situations the administration collected the questionnaires and administered them later in situations where the teachers were not present. The researcher, however, collected them later for analysis.

\section{Method of Data Analysis}

The data obtained from the research instrument has been analyzed both descriptively and inferentially. This has been done by first doing an item-by-item and then section analyses.

Descriptively, simple and relative frequencies (percentages) per response option have been calculated and used to describe the trends in respondents' responses, classified according to and compared according to their first or main teaching subjects (History, Geography, Economics and Philosophy/Religion). Relative frequencies or percentages have been calculated using the formula Relative frequency (percentage) of a response option $=$

Respottse Frequency

Totalfrequency 
Inferentially, the chi squared statistic has been used to test for whether or not the summary of Citizenship teachers' opinions (at the end of every section of the questionnaire) depend on their first or main teaching subjects (History, Geography, Economics and Philosophy/Religion). This uses two parameters - the chi squared statistic and the degree of freedom, where:

Chi squared $\left(j^{2}\right)=£\left(\stackrel{\circ}{ }^{\mathrm{E}}\right)_{\mathrm{s}}$ where $\mathrm{O}=$ observed frequency,

$\mathrm{E}=$ expected frequency and ${ }^{\wedge}=$ 'Sum of

Degree of freedom $(d f)=(c-1)+(r-1)$ or $(c+r-2)$.

$\mathrm{c}=$ number of columns and $\mathrm{r}$ number of rows in the contingency table

\section{Demographic Information} Item $\backslash \backslash$ Gender

\section{FINDINGS}

The data has been analyzed both descriptively and inferentially. Descriptively, the responses to the questionnaire have been analyzed item by item and section by section using simple frequencies and percentages in search for trends on the perception of Citizenship Education Teachers.

Inferentially, the chi-squared statistic has been used to test whether or not Citizenship Education teachers' perception of the subject depends on their major or first teaching subject and the school where they teach.

\begin{tabular}{|l|c|c|c|c|}
\hline Gender & & Male & Female & Total \\
\hline \multirow{2}{*}{ History } & $\mathrm{f}$ & 48 & 30 & 78 \\
\cline { 2 - 5 } & $\%$ & $61.5 \%$ & $38.5 \%$ & $100 \%$ \\
\hline \multirow{2}{*}{ Geography } & $\mathrm{f}$ & 24 & 18 & 42 \\
\cline { 2 - 5 } & $\%$ & $57.1 \%$ & $42.9 \%$ & $100 \%$ \\
\hline \multirow{2}{*}{ Economics } & $\mathrm{f}$ & 15 & 09 & 24 \\
\cline { 2 - 5 } & $\%$ & $62.5 \%$ & $37.5 \%$ & $100 \%$ \\
\hline \multirow{2}{*}{ Philosophy / Religion } & $\mathrm{f}$ & 04 & 02 & 06 \\
\cline { 2 - 5 } & $\%$ & $66.7 \%$ & $33.3 \%$ & $100 \%$ \\
\hline \multirow{2}{*}{ All Subjects (Total) } & $\mathrm{f}$ & 91 & 59 & 150 \\
\cline { 2 - 5 } & $\%$ & $60.7 \%$ & $39.3 \%$ & $100 \%$ \\
\hline
\end{tabular}

By gender, about three out of every five Citizenship Education teachers are mates white the other two are females. Although this distribution of teachers by sex does not vary much with the main teaching subjects (History, Geography, Economics and Philosophy/Religion), the highest proportion of male Citizenship Education teachers are Philosophy/Religion teachers $(66.7 \%)$ while the highest proportion of female teachers originally teach Geography (42.9\%).

\begin{tabular}{|l|c|c|c|c|}
\multicolumn{2}{c|}{ Item 2: Location } \\
\hline Location & & Urban & Rural & Total \\
\hline \multirow{2}{*}{ History } & $\mathrm{f}$ & 36 & 42 & 78 \\
\cline { 2 - 5 } & $\%$ & $46.2 \%$ & $53.5 \%$ & $100 \%$ \\
\hline \multirow{2}{*}{ Geography } & $\mathrm{f}$ & 24 & 18 & 42 \\
\cline { 2 - 5 } & $\%$ & $57.1 \%$ & $42.9 \%$ & $100 \%$ \\
\hline \multirow{2}{*}{ Economics } & $\mathrm{f}$ & 12 & 12 & 24 \\
\cline { 2 - 5 } & $\%$ & $50.0 \%$ & $50.0 \%$ & $100 \%$ \\
\hline \multirow{2}{*}{ Philosophy / Religion } & $\mathrm{f}$ & 04 & 02 & 06 \\
\cline { 2 - 5 } & $\%$ & $66.7 \%$ & $33.3 \%$ & $100 \%$ \\
\hline \multirow{2}{*}{ All Subjects (Total) } & $\mathrm{f}$ & 76 & 74 & 150 \\
\cline { 2 - 5 } & $\%$ & $50.7 \%$ & $49.3 \%$ & $100 \%$ \\
\hline
\end{tabular}

Citizenship Education teachers are almost equally distributed between the urban $(50.7 \%)$ and the rural (49.3\%) schools. While the urban schools have more Philosophy teachers (66.7\%), the Economics teachers are equally shared (50-50) between the urban and rural schools. Also, there are slightly mere urban Geography teachers $(57.1 \%)$ and more rural History teachers $(53.5 \%)$. 
International Journal of Trend in Scientific Research and Development (IJTSRD) ISSN: 2456-6470

Item 3: Main Subject

\begin{tabular}{|c|c|c|c|c|c|}
\hline Subject & History & Geography & Economics & Phil/Religion & Total \\
\hline $\mathrm{f}$ & 78 & 42 & 24 & 06 & 150 \\
\hline$\%$ & $52.0 \%$ & $28.0 \%$ & $16.0 \%$ & $4.0 \%$ & $100 \%$ \\
\hline
\end{tabular}

More than half (52\%) of Citizenship Education teachers are History teachers while the least number of them are Philosophy /Religion teachers (4\%). The remaining 44\% of the teachers are either Geography teachers $(28 \%)$ or Economics teachers (16\%). It is evident that a majority of (although not absolute) Citizenship Education teachers are History teachers.

Item 4: Longevity

\begin{tabular}{|c|c|c|c|c|c|c|c|}
\hline \multirow{2}{*}{ Longevity } & & $0-4$ & $5-9$ & $10-14$ & $15-19$ & $20+$ & Total \\
\hline \multirow{2}{*}{ History } & $\mathrm{f}$ & 36 & 24 & 18 & 0 & 0 & 78 \\
\cline { 2 - 9 } & $\%$ & $46.1 \%$ & $30.8 \%$ & $23.1 \%$ & $0 \%$ & $0 \%$ & $100 \%$ \\
\hline \multirow{2}{*}{ Geography } & $\mathrm{f}$ & 24 & 06 & 0 & 12 & 0 & 42 \\
\cline { 2 - 9 } & $\%$ & $57.1 \%$ & $14.3 \%$ & $0 \%$ & $28.6 \%$ & $0 \%$ & $100 \%$ \\
\hline \multirow{2}{*}{ Economics } & $\mathrm{f}$ & 06 & 12 & 06 & 0 & 0 & 24 \\
\cline { 2 - 9 } & $\%$ & $25.0 \%$ & $50.0 \%$ & $25.0 \%$ & $0 \%$ & $0 \%$ & $100 \%$ \\
\hline \multirow{3}{*}{ Philosophy / Religion } & $\mathrm{f}$ & 03 & 02 & 01 & 0 & 0 & 06 \\
\cline { 2 - 9 } & $\%$ & $50.0 \%$ & $33.3 \%$ & $16.7 \%$ & $0 \%$ & $0 \%$ & $100 \%$ \\
\hline \multirow{2}{*}{ All Subjects (Total) } & $\mathrm{f}$ & 69 & 44 & 25 & 12 & 0 & 150 \\
\cline { 2 - 9 } & $\%$ & $46.0 \%$ & $29.3 \%$ & $16.7 \%$ & $8.0 \%$ & $0 \%$ & $100 \%$ \\
\hline Cumulative \% & $46.0 \%$ & $75.3 \%$ & $92.0 \%$ & $100 \%$ & $\%$ & - \\
\hline
\end{tabular}

While almost half of the teachers (46\%) have taught for four years and below, three quarters have taught for up to 9 years and a sixth $(16.7 \%)$ have taught for 10 to 14 years.

Item 5: Classes taught

\begin{tabular}{|c|c|c|c|c|c|c|c|c|c|}
\hline Class & & Fl & $\mathrm{F} 2$ & F3 & F4 & F5 & L6 &. $\mathrm{U6}$ & Total \\
\hline \multirow{2}{*}{ History } & $\mathrm{f}$ & 30 & 42 & 38 & 40 & 15 & 10 & 08 & 183 \\
\hline & $\%$ & $16.4 \%$ & $23.0 \%$ & $20.8 \%$ & $21.9 \%$ & $8.2 \%$ & $5.5 \%$ & $4.4 \%$ & $100 \%$ \\
\hline \multirow{2}{*}{ Geography } & $\mathrm{f}$ & 18 & 18 & 18 & 18 & 06 & 12 & 04 & 94 \\
\hline & $\%$ & $19.1 \%$ & $19.1 \%$ & $19.1 \%$ & $19.1 \%$ & $6.4 \%$ & $12.8 \%$ & $4.3 \%$ & $100 \%$ \\
\hline \multirow{2}{*}{ Economics } & $\mathrm{f}$ & 12 & 06 & 12 & 15 & 05 & 04 & 02 & 56 \\
\hline & $\%$ & $21.4 \%$ & $10.7 \%$ & $21.4 \%$ & $26.9 \%$ & $8.9 \%$ & $7.1 \%$ & $3.6 \%$ & $100 \%$ \\
\hline \multirow{2}{*}{ Philosophy / Religion } & $\mathrm{f}$ & 01 & 0 & 03 & 02 & 03 & 02 & 02 & 13 \\
\hline & $\%$ & $7.7 \%$ & $0 \%$ & $23.1 \%$ & $15.4 \%$ & $23.1 \%$ & $15.4 \%$ & $15.4 \%$ & $100 \%$ \\
\hline \multirow{3}{*}{ All Subjects (Total) } & $\mathrm{f}$ & 61 & 66 & 71 & 75 & 29 & 28 & 16 & 346 \\
\hline & $\%$ & $17.6 \%$ & $19.1 \%$ & $20.5 \%$ & $21.7 \%$ & $8.4 \%$ & $8.1 \%$ & $4.6 \%$ & $100 \%$ \\
\hline & & \multicolumn{3}{|c|}{$57.5 \%$} & \multicolumn{2}{|c|}{$30.0 \%$} & \multicolumn{2}{|c|}{$12.5 \%$} & \\
\hline
\end{tabular}

About three fifths (57.5\%) of all the teachers sampled teach in the junior secondary school (Forms i, 2 and 3), while three tenths $(30 \%)$ teach in the senior secondary and one eighth (12.5\%) teach in high school (Lower and Upper Sixths). 
International Journal of Trend in Scientific Research and Development (IJTSRD) ISSN: 2456-6470

Item 6: Highest Academic Qualification

\begin{tabular}{|l|c|c|c|c|c|c|}
\hline \multicolumn{1}{|c|}{ Qualification } & & Bachelors & Masters & Doctorate & Others & Total \\
\hline \multirow{2}{*}{ History } & $\mathrm{f}$ & 72 & 0 & 0 & 06 & 78 \\
\cline { 2 - 7 } & $\%$ & $92.3 \%$ & $0 \%$ & $0 \%$ & $7.7 \%$ & $100 \%$ \\
\hline \multirow{2}{*}{ Geography } & $\mathrm{f}$ & 24 & 0 & 0 & 18 & 42 \\
\cline { 2 - 7 } & $\%$ & $57.1 \%$ & $0 \%$ & $0 \%$ & $42.9 \%$ & $100 \%$ \\
\hline \multirow{2}{*}{ Economics } & $\mathrm{f}$ & 15 & 0 & 0 & 09 & 24 \\
\cline { 2 - 7 } & $\%$ & $62.5 \%$ & $0 \%$ & $0 \%$ & $37.5 \%$ & $100 \%$ \\
\hline \multirow{2}{*}{ Philosophy /Religion } & $\mathrm{f}$ & 03 & 01 & 0 & 02 & 06 \\
\cline { 2 - 7 } & $\%$ & $50.0 \%$ & $16.7 \%$ & $0 \%$ & $33.3 \%$ & $100 \%$ \\
\hline \multirow{2}{*}{ All Subjects (Total) } & $\mathrm{f}$ & 114 & 01 & 0 & 35 & 150 \\
\cline { 2 - 7 } & $\%$ & $76.0 \%$ & $0.7 \%$ & $0 \%$ & $23.3 \%$ & $100 \%$ \\
\hline
\end{tabular}

More than three quarters (76\%) of all Citizenship Education teachers hold Bachelors degrees; the highest of this category being History teachers (92.3\%) and the least being Philosophy / Religion teachers (50\%). Also, about a fifth $(23.3 \%)$ of the sampled teachers hold certificates other than Bachelors and none hold the doctorate degree. Very few $(0.7 \%)$ hold Masters Degrees; a comparative majority of whom are Philosophy/Religion teachers $(16.7 \%)$.

Item 7: Highest Professional Qualification

\begin{tabular}{|c|c|c|c|c|c|c|}
\hline Qualification & & T G I & DIPESI & DIPES II & Others & Total \\
\hline \multirow{2}{*}{ History } & $\mathrm{f}$ & 02 & 48 & 24 & 04 & 78 \\
\hline & $\%$ & $1.3 \%$ & $61.5 \%$ & $30.8 \%$ & $5.1 \%$ & $100 \%$ \\
\hline \multirow{2}{*}{ Geography } & $\mathrm{f}$ & 0 & 18 & 24 & 0 & 42 \\
\hline & $\%$ & $0 \%$ & $42.9 \%$ & $57.1 \%$ & $0 \%$ & $100 \%$ \\
\hline \multirow{2}{*}{ Economics } & $\mathrm{f}$ & 0 & 18 & 0 & 06 & 24 \\
\hline & $\%$ & $\%$ & $75.0 \%$ & $0 \%$ & $25.0 \%$ & $100 \%$ \\
\hline \multirow{2}{*}{ Philosophy / Religion } & $f$ & 01 & 01 & 01 & 03 & 06 \\
\hline & $\%$ & $16.7 \%$ & $16.7 \%$ & $16.7 \%$ & $50.0 \%$ & $100 \%$ \\
\hline \multirow{2}{*}{ All Subjects (Total) } & $\mathrm{f}$ & $03 \mathrm{e}$ & $0 / 8510$ & 49 & 13 & 150 \\
\hline & $\%$ & $2.0 \%$ & $56.7 \%$ & $32.7 \%$ & $8.7 \%$ & $100 \%$ \\
\hline
\end{tabular}

Professionally, more than half of the teachers of Citizenship Education (56.7\%) hold the DIPES I Teachers' Certificate and about a third others $(32.7 \%)$ hold the DIPES II Teachers' Certificate. This distribution varies from a low $16.7 \%$ for Philosophy /Religion to $75 \%$ for Economics for DIPES I and 16.7\% for Philosophy /Religion to $57.1 \%$ for Geography for DIPES II. Also, about a tenth $(10.7 \%)$ of the teachers holds other certificates, including Teachers' Grade I Certificate - a majority of who are the Philosophy/Religion Teachers $(50 \%)$.

Analyses and Findings of Research Question: Is there a relationship between challenges encountered by teachers as a result of their quality in teaching Citizenship.

1:1 have been trained in my main subject discipline

\begin{tabular}{|c|c|c|c|c|c|c|c|}
\hline Sulbject & & SA & A & D & SD & u & Total \\
\hline \multirow{2}{*}{ History } & $\mathrm{f}$ & 35 & 42 & 01 & 0 & 0 & 78 \\
\cline { 2 - 8 } & $\%$ & $44.9 \%$ & $53.9 \%$ & $1.2 \%$ & $0 \%$ & $0 \%$ & $100 \%$ \\
\hline \multirow{2}{*}{ Geography } & $\mathrm{f}$ & 15 & 21 & 06 & 0 & 0 & 42 \\
\cline { 2 - 8 } & $\%$ & $35.7 \%$ & $50.0 \%$ & $14.3 \%$ & $0 \%$ & $0 \%$ & $100 \%$ \\
\hline \multirow{2}{*}{ Economics } & $\mathrm{f}$ & 18 & 0 & 06 & 0 & 0 & 24 \\
\cline { 2 - 9 } & $\%$ & $75.0 \%$ & $0 \%$ & $25.0 \%$ & $0 \%$ & $0 \%$ & $100 \%$ \\
\hline \multirow{2}{*}{ Philosophy /Religion } & $\mathrm{f}$ & 02 & 03 & 01 & 0 & 0 & 06 \\
\cline { 2 - 9 } & $\%$ & $33.3 \%$ & $50.0 \%$ & $16.7 \%$ & $0 \%$ & $0 \%$ & $100 \%$ \\
\hline \multirow{2}{*}{ All Subjects (Total) } & $\mathrm{f}$ & 70 & 66 & 14 & 0 & 0 & 150 \\
\cline { 2 - 8 } & $\%$ & $46.7 \%$ & $44.0 \%$ & $9.3 \%$ & $0 \%$ & $0 \%$ & $100 \%$ \\
\hline & & 90. & $7 \%$ & $9 .$. & $3 \%$ & & \\
\hline
\end{tabular}


International Journal of Trend in Scientific Research and Development (IJTSRD) ISSN: 2456-6470

1:1 have been trained in my main subject discipline

\begin{tabular}{|c|c|c|c|r|r|c|c|}
\hline Sulbject & & SA & A & D & SD & u & Total \\
\hline \multirow{2}{*}{ History } & $\mathrm{f}$ & 35 & 42 & 01 & 0 & 0 & 78 \\
\cline { 2 - 9 } & $\%$ & $44.9 \%$ & $53.9 \%$ & $1.2 \%$ & $0 \%$ & $0 \%$ & $100 \%$ \\
\hline \multirow{2}{*}{ Geography } & $\mathrm{f}$ & 15 & 21 & 06 & 0 & 0 & 42 \\
\cline { 2 - 9 } & $\%$ & $35.7 \%$ & $50.0 \%$ & $14.3 \%$ & $0 \%$ & $0 \%$ & $100 \%$ \\
\hline \multirow{2}{*}{ Economics } & $\mathrm{f}$ & 18 & 0 & 06 & 0 & 0 & 24 \\
\cline { 2 - 9 } & $\%$ & $75.0 \%$ & $0 \%$ & $25.0 \%$ & $0 \%$ & $0 \%$ & $100 \%$ \\
\hline \multirow{2}{*}{ Philosophy / Religion } & $\mathrm{f}$ & 02 & 03 & 01 & 0 & 0 & 06 \\
\cline { 2 - 9 } & $\%$ & $33.3 \%$ & $50.0 \%$ & $16.7 \%$ & $0 \%$ & $0 \%$ & $100 \%$ \\
\hline \multirow{2}{*}{ All Subjects (Total) } & $\mathrm{f}$ & 70 & 66 & 14 & 0 & 0 & 150 \\
\cline { 2 - 9 } & $\%$ & $46.7 \%$ & $44.0 \%$ & $9.3 \%$ & $0 \%$ & $0 \%$ & $100 \%$ \\
\hline & & 90. & $7 \%$ & $9 .$. & $3 \%$ & & \\
\hline
\end{tabular}

A majority (90.7\%) of the teachers of Citizenship Education have received training in their main or teaching subjects; most of whom are History teachers (98.8\%) and the least being Economics (7 5.0\%)

Item 2: I have been trained to teach Citizenship

\begin{tabular}{|c|c|c|c|c|c|c|c|}
\hline Subject & & SA & A & D & SD & U & Total \\
\hline History & $\mathrm{f}$ & 13 & 31 & 20 & 14 & 0 & 78 \\
\hline & $\%$ & $16.7 \%$ & $39.7 \%$ & $25.6 \%$ & $18.0 \%$ & $0 \%$ & $100 \%$ \\
\hline Geography & $\mathrm{f}$ & 0 & 0 & 24 & 18 & 0 & 42 \\
\hline & $\%$ & $0 \%$ & $0 \%$ & $57.1 \%$ & $42.9 \%$ & $0 \%$ & $100 \%$ \\
\hline Economics & $\mathrm{f}$ & 03 & 03 & 06 & 12 & 0 & 24 \\
\hline & $\%$ & $12.5 \%$ & $12.5 \%$ & $25.0 \%$ & $50.0 \%$ & $0 \%$ & $100 \%$ \\
\hline Philosophy/Religion & $\mathrm{f}$ & 0 & 0 & 03 & 02 & 01 & 06 \\
\hline & $\%$ & $0 \%$ & $0 \%$ & $50.0 \%$ & $33.3 \%$ & $16.7 \%$ & $100 \%$ \\
\hline All Subjects (Total) & $\mathrm{f}$ & 16 & 234 & 53 & 46 & 01 & 150 \\
\hline & $\%$ & $10.7 \%$ & $22.7 \%$ & $35.3 \%$ & $30.7 \%$ & $0.7 \%$ & $100 \%$ \\
\hline & & $33.3 \%$ & $66.0 \%$ & & \\
\hline
\end{tabular}

While about two thirds $(66 \%)$ of all the teachers have not received training in the teaching of Citizenship Education, the situation is more acute with Geography (none of whom has been trained to teach Citizenship Education) and Philosophy /Religion teachers (83.3\% of whom have not been trained). About half of the History teachers $(56.4 \%)$ and a quarter $(25.0 \%)$ of the Economics teachers have been trained to teach Citizenship Education.

Item 3: Training in Citizenship Education was obtained in

\begin{tabular}{|c|c|c|c|c|c|c|}
\hline Subject & & TTC & Sem & Wks & SRCE & Total \\
\hline \multirow{2}{*}{ History } & $\mathrm{f}$ & 18 & 18 & 36 & 30 & 102 \\
\cline { 2 - 7 } & $\%$ & $17.6 \%$ & $17.6 \%$ & $35.3 \%$ & $29.4 \%$ & $100 \%$ \\
\hline \multirow{2}{*}{ Geography } & $\mathrm{f}$ & 0 & 12 & 12 & 24 & 48 \\
\cline { 2 - 7 } & $\%$ & $0 \%$ & $25.0 \%$ & $25.0 \%$ & $50.0 \%$ & $100 \%$ \\
\hline \multirow{2}{*}{ Economics } & $\mathrm{f}$ & 03 & 03 & 09 & 12 & 27 \\
\cline { 2 - 7 } & $\%$ & $11.1 \%$ & $11.1 \%$ & $33.3 \%$ & $44.4 \%$ & $100 \%$ \\
\hline \multirow{2}{*}{ Philosophy / Religion } & $\mathrm{f}$ & 0 & 02 & 01 & 03 & 06 \\
\cline { 2 - 7 } & $\%$ & $0 \%$ & $33.3 \%$ & $16.7 \%$ & $50.0 \%$ & $100 \%$ \\
\hline \multirow{2}{*}{ All Subjects (Total) } & $\mathrm{f}$ & 21 & 35 & 58 & 69 & 150 \\
\cline { 2 - 7 } & $\%$ & $11.5 \%$ & $19.1 \%$ & $31.7 \%$ & $37.7 \%$ & $100 \%$ \\
\hline
\end{tabular}


This item actually deals with the quality of the teachers who teach Citizenship. Though most teachers have been trained in their main subject disciplines, in Citizenship, only $11.5 \%$ got trained in Teacher Training Colleges which is the lowest when compared with the $19.1 \%$ and $31.7 \%$ who were trained through Seminars and Workshops respectively. A relatively highest proportion of the teachers $(37.7 \%)$ trained themselves through Self Reading of Citizenship Education materials. Although this group is the most popular, it is still below average expectation. However, half (50\%) of Geography and Philosophy/Religion teachers trainedthemselves on Citizenship Education. From the foregoing, it is evident most of the teachers of Citizenship from all the subject areas have not been formally trained to teach the subject.

Item 4: Social Science teachers should teach Citizenship

\begin{tabular}{|c|c|c|c|c|c|c|c|}
\hline Sulbject & & SA & A & D & SD & $\mathrm{U}$ & Total \\
\hline \multirow{2}{*}{ History } & $\mathrm{f}$ & 30 & 42 & 06 & 0 & 0 & 78 \\
\hline & $\%$ & $29.4 \%$ & $53.9 \%$ & $7.7 \%$ & $0 \%$ & $0 \%$ & $100 \%$ \\
\hline \multirow{2}{*}{ Geography } & $\mathrm{f}$ & 12 & 18 & 06 & 06 & 0 & 42 \\
\hline & $\%$ & $28.6 \%$ & $42.9 \%$ & $14.3 \%$ & $14.3 \%$ & $0 \%$ & $100 \%$ \\
\hline \multirow{2}{*}{ Economics } & $f$ & 09 & 12 & 0 & 03 & 0 & 24 \\
\hline & $\%$ & $37.5 \%$ & $50.0 \%$ & $0 \%$ & $12.5 \%$ & $0 \%$ & $100 \%$ \\
\hline \multirow{2}{*}{ Philosophy / Religion } & $\mathrm{f}$ & 02 & 0 & 0 & 04 & 0 & 06 \\
\hline & $\%$ & $33.3 \%$ & $0 \%$ & $0 \%$ & $66.7 \%$ & $0 \%$ & $100 \%$ \\
\hline \multirow{2}{*}{ All Subjects (Total) } & $\mathrm{f}$ & 53 & 72 & 12 & 13 & 0 & 150 \\
\hline & $\%$ & $35.3 \%$ & $48.0 \%$ & $8.0 \%$ & $8.7 \%$ & $0 \%$ & $100 \%$ \\
\hline 8 & e & na 83. & & our 1 & $7 \%$ & & 5 \\
\hline
\end{tabular}

More than four fifths $(83.3 \%)$ of the teachers agreed that Citizenship should be thought by Social Science teachers while about a fifth (16.7\%) disagreed. Although $87.5 \%, 83.3 \%$, and $71.5 \%$ of Economics, History and Geography teachers respectively agreed with the issue raised, the situation is more acute with Philosophy/ Religion teachers where only a third (33.3\%) agreed, two thirds (66.7\%) disagreed. Their disagreement is however low when compared with the agreement levels of the other three subjects respectively as well as the general $83.3 \%$ point.

Item 5: Citizenship should be taught

\begin{tabular}{|c|c|c|c|c|c|c|}
\hline Subject & & (i) & (ii) & (iii) & (iv) & Total \\
\hline \multirow{2}{*}{ History } & $\mathrm{f}$ & 0 & 45 & 33 & 0 & 78 \\
\cline { 2 - 7 } & $\%$ & $0 \%$ & $57.8 \%$ & $42.3 \%$ & $0 \%$ & $100 \%$ \\
\hline \multirow{2}{*}{ Geography } & $\mathrm{f}$ & 0 & 30 & 12 & 0 & 42 \\
\cline { 2 - 7 } & $\%$ & $0 \%$ & $71.4 \%$ & $28.6 \%$ & $0 \%$ & $100 \%$ \\
\hline \multirow{2}{*}{ Economics } & $\mathrm{f}$ & 0 & 09 & 15 & 0 & 24 \\
\cline { 2 - 7 } & $\%$ & $0 \%$ & $37.5 \%$ & $62.5 \%$ & $0 \%$ & $100 \%$ \\
\hline \multirow{2}{*}{ Philosophy / Religion } & $\mathrm{f}$ & 01 & 03 & 02 & 0 & 06 \\
\cline { 2 - 7 } & $\%$ & $16.7 \%$ & $50.0 \%$ & $33.3 \%$ & $0 \%$ & $100 \%$ \\
\hline \multirow{2}{*}{ All Subjects (Total) } & $\mathrm{f}$ & 01 & 87 & 62 & 0 & 150 \\
\cline { 2 - 7 } & $\%$ & $0.7 \%$ & $58.0 \%$ & $41.3 \%$ & $0 \%$ & $100 \%$ \\
\hline
\end{tabular}

More than half $58.0 \%$ of teachers hold the opinion that Citizenship should be thought once a week. This comes from the strongest position of the Geography teachers with 71.4 to a weak $37.5 \%$ from Economics teachers. $41.3 \%$ accept that the subject should be thought more than once a week even though this is less than average. Only teachers of Philosophy/Religion thought that it should be taught occasionally. However all the teachers 100\% kicked against the issue that Citizenship should never be thought. 
International Journal of Trend in Scientific Research and Development (IJTSRD) ISSN: 2456-6470

Item 6: Social science teachers should be trained to teach Citizenship Education

\begin{tabular}{|c|c|c|c|c|c|c|c|}
\hline Sulbject & & SA & A & D & SD & u & Total \\
\hline \multirow{2}{*}{ History } & $\mathrm{f}$ & 24 & 36 & 18 & 0 & 0 & 78 \\
\cline { 2 - 9 } & $\%$ & $30.8 \%$ & $46.2 \%$ & $23.1 \%$ & $0 \%$ & $0 \%$ & $100 \%$ \\
\hline \multirow{2}{*}{ Geography } & $\mathrm{f}$ & 18 & 24 & 0 & 0 & 0 & 42 \\
\cline { 2 - 9 } & $\%$ & $42.9 \%$ & $57.1 \%$ & $0 \%$ & $0 \%$ & $0 \%$ & $100 \%$ \\
\hline \multirow{2}{*}{ Economics } & $\mathrm{f}$ & 12 & 12 & 0 & 0 & 0 & 24 \\
\cline { 2 - 9 } & $\%$ & $50.0 \%$ & $50.0 \%$ & $0 \%$ & $0 \%$ & $0 \%$ & $100 \%$ \\
\hline \multirow{2}{*}{ Philosophy / Religion } & $\mathrm{f}$ & 04 & 02 & 0 & 0 & 0 & 06 \\
\cline { 2 - 9 } & $\%$ & $66.7 \%$ & $33.3 \%$ & $0 \%$ & $0 \%$ & $0 \%$ & $100 \%$ \\
\hline \multirow{2}{*}{ All Subjects (Total) } & $\mathrm{f}$ & 58 & 74 & 18 & 0 & 0 & 150 \\
\cline { 2 - 8 } & $\%$ & $38.7 \%$ & $49.3 \%$ & $12.0 \%$ & $0 \%$ & $0 \%$ & $100 \%$ \\
\hline & & \multicolumn{2}{|c|}{$88.0 \%$} & $12.0 \%$ & & \\
\hline
\end{tabular}

The need for Social Science teachers to be trained to teach Citizenship is overwhelmingly accepted with an 88.0\%. This portrays a 100\% acceptance from all the teachers of Geography, Economics and Philosophy/Religion. Just a negligible $12.0 \%$ disagreed; all of whom are History teachers. This proportion is insignificant; especially when compared with the $77 \%$ who agreed with the issue raised.

Item 7: Citizenship education topic areas outside specialization are taught with difficulties

\begin{tabular}{|c|c|c|c|c|c|c|c|}
\hline \multirow{2}{*}{ Subject } & & SA & A & D & SD & $\mathrm{U}$ & Total \\
\hline & $f$ & 24 & 24 & 24 & 06 & 0 & 78 \\
\hline History & $\%$ & $30.8 \%$ & $30.8 \%$ & $30.8 \%$ & $7.7 \%$ & $0 \%$ & $100 \%$ \\
\hline \multirow{2}{*}{ Geography } & $\mathrm{f}$ & 0 & 0 & 18 & 24 & 0 & 42 \\
\hline & $\%$ & $0 \%$ & $0 \%$ & $42.9 \%$ & $57.1 \%$ & $0 \%$ & $100 \%$ \\
\hline \multirow{2}{*}{ Economics } & $\mathrm{f}$ & 06 & 09 & 06 & 03 & 0 & 24 \\
\hline & $\%$ & $25.0 \%$ & $37.5 \%$ & $25.0 \%$ & $12.5 \%$ & $0 \%$ & $100 \%$ \\
\hline \multirow{2}{*}{ Philosophy / Religion } & $f$ & 02 & 1102 & 170 & 02 & 0 & 06 \\
\hline & $\%$ & $33.3 \%$ & $33.3 \%$ & $0 \%$ & $33.3 \%$ & $0 \%$ & $100 \%$ \\
\hline \multirow{2}{*}{ All Subjects (Total) } & $\mathrm{f}$ & 32 & 35 & 48 & 35 & 0 & 150 \\
\hline & $\%$ & $21.3 \%$ & $23.3 \%$ & $32.0 \%$ & $23.3 \%$ & $0 \%$ & $100 \%$ \\
\hline
\end{tabular}

While the teachers' opinion on the difficulties of teaching topic areas outside their specialization is almost shared between disagreement $(55.3 \%)$ and agreement $(44.7 \%)$, the ruling is generally in favour of disagreement. This means that the teachers generally do not find difficulties teaching topic areas outside their specializations or main teaching subjects. In this direction, the Geography teachers are the most comfortable as none of them find any difficulties, while the History (38.5\%), Economics (37.5\%) and Philosophy/Religion teachers $(33.1 \%)$ are the most uncomfortable in teaching topic areas outside their specializations.

Summary: Quality of Citizenship Education Teacher

\begin{tabular}{|c|c|c|c|c|c|c|c|}
\hline Sulbject & & SA & A & D & SD & U & Total \\
\hline \multirow{2}{*}{ History } & $\mathrm{f}$ & 126 & 175 & 69 & 20 & 0 & 390 \\
\cline { 2 - 8 } & $\%$ & $32.3 \%$ & $44.9 \%$ & $17.7 \%$ & $5.1 \%$ & $0 \%$ & $100 \%$ \\
\hline \multirow{2}{*}{ Geography } & $\mathrm{f}$ & 45 & 63 & 54 & 48 & 0 & 210 \\
\cline { 2 - 9 } & $\%$ & $21.4 \%$ & $30.0 \%$ & $25.7 \%$ & $22.9 \%$ & $0 \%$ & $100 \%$ \\
\hline \multirow{2}{*}{ Economics } & $\mathrm{f}$ & 48 & 36 & 18 & 18 & 0 & 120 \\
\cline { 2 - 9 } & $\%$ & $40.0 \%$ & $30.0 \%$ & $15.0 \%$ & $15.0 \%$ & $0 \%$ & $100 \%$ \\
\hline \multirow{2}{*}{ Philosophy / Religion } & $\mathrm{f}$ & 10 & 07 & 04 & 08 & 01 & 30 \\
\cline { 2 - 8 } & $\%$ & $33.3 \%$ & $23.3 \%$ & $13.3 \%$ & $26.7 \%$ & $3.3 \%$ & $100 \%$ \\
\hline \multirow{2}{*}{ All Subjects (Total) } & $\mathrm{f}$ & 229 & 281 & 145 & 94 & 01 & 750 \\
\cline { 2 - 8 } & $\%$ & $30.5 \%$ & $37.5 \%$ & $19.3 \%$ & $12.5 \%$ & $0.1 \%$ & $100 \%$ \\
\hline & & $68.0 \%$ & $31.9 \%$ & & \\
\hline
\end{tabular}


In reaction to the quality of Citizenship Education teachers, more than two thirds $(68 \%)$ of all the teachers agreed with the issues raised while about a third of them (31.9\%) disagreed. The variation in agreement ranges from that of the most positive History teachers (77.2\%) through those of the Economics (70\%) and Philosophy/Religion teachers $(56.6 \%)$ to that of the least positive Geography teachers $(51.4 \%)$. The chi squared statistic has been established below to determine the extent to which this variation significantly depends on the Citizenship Education teachers' main or first teaching subject.

\section{The Chi Squared Statistic}

Contingency table summarizing the respondents' opinions on this aspect

\begin{tabular}{|c|c|c|c|c|c|c|}
\hline Subject & SA & A & D & SD & U & Total \\
\hline History & 126 & 175 & 69 & 20 & 0. & 390 \\
\hline Geography & 45 & 63 & 54 & 48 & 0 & 210 \\
\hline Economics & 48 & 36 & 18 & 18 & 0 & 120 \\
\hline Philosophy / Religion & 10 & 07 & 04 & 08 & 01 & 30 \\
\hline Total & 229 & 281 & 145 & 94 & 01 & 750 \\
\hline
\end{tabular}

Calculation of the chi-squared statistic

\begin{tabular}{|c|c|c|c|c|}
\hline $\boldsymbol{0}$ & $\mathrm{E}$ & $\mathbf{O}-\mathrm{E}$ & $(\mathbf{O}-\mathrm{E})^{2}$ & $(\mathbf{O}-\mathrm{E})^{2}-5-\mathrm{E}$ \\
\hline 126 & 119 & 7 & 49 & 0.412 \\
\hline 175 & 146 & 29 & 841 & 5.760 \\
\hline 69 & 75.4 & -6.4 & 40.96 & 0.543 \\
\hline 20 & 49 & -29 & 841 & 17.163 \\
\hline 0 & 0.5 & -0.5 & 0.25 & 0.500 \\
\hline 45 & 64 & -19 & 361 & 5.641 \\
\hline 63 & 78.7 & -15.7 & 246.49 & 3.132 \\
\hline 54 & 40.6 & 13.4 & 179.56 & 4.423 \\
\hline 48 & 26.3 & 21.7 & 470.89 & 17.905 \\
\hline 0 & 0.3 & -0.3 & 0.09 & 0.300 \\
\hline 48 & 36.6 & 11.6 & 129.96 & 3.551 \\
\hline 36 & 45 & -9 & 81 & 1.800 \\
\hline 18 & 23.2 & -5.2 & 27.04 & 1.166 \\
\hline 18 & 15 & 3 & 9 & 0.600 \\
\hline 0 & 0.2 & -0.2 & 0.04 & 0.200 \\
\hline 10 & 9.2 & 0.8 & 0.64 & 0.070 \\
\hline 7 & 11.2 & -4.2 & 17.64 & 1.575 \\
\hline 4 & 5.8 & -1.8 & 3.24 & 0.559 \\
\hline 8 & 3.8 & 4.2 & 17.64 & 4.642 \\
\hline 1 & 0.1 & 0.9 & 0.81 & 8.100 \\
\hline & & $\%$ cal & & 78.042 \\
\hline
\end{tabular}

$\mathrm{df}=(4-1)(5-1)=3 \times 4=12$

$z U d f=12, \mathrm{si}=0.05)=21.026$ and 78.042

$£[<,:$ The quality of Citizenship Education Teachers does not significantly depend on their first teaching subject.

$\mathrm{H}^{\wedge}$ Thequality of Citizenship Education Teachers significantly depends on their first teaching subject.

Contingency

Coefficient

(cc)

$=$

$\mathrm{V}=\mathbf{i 7 8 . 0 4 2}-\mathrm{V}^{\wedge} \mathrm{SJ}$

$V_{\|}+{ }^{\wedge 2} V \overline{750}+\mathbf{7 8 . 0 4 2} V \mathbf{8 2 8 . 0 4 2}$

\section{0"3070}

Hence $\mathrm{cc}=0.31$ (on a cc max of 0.7071$)$, which is ${ }^{\wedge \wedge} \mathrm{xioo} \%=43.4 \%$. 


\section{Decision}

Since $z L W=12, \mathrm{si}=0.05)=2 \backslash m 6<x^{2} c a l=78.042$, the null hypothesis (Ho) is rejected (and the alternative hypothesis (Ha) is accepted). Hence, at the $95 \%$ level of confidence, the quality of Citizenship Education teachers depends on their initial teaching subject.

\section{Conclusion}

Generally, about two thirds (68\%) of all the teachers agreed with the issues raised. This position varies significantly between the teachers of History, Geography, Economics and Philosophy/Religion; with History teachers being most positive and Geography teachers being the least positive.

\section{The major findings of this project show that:}

$>$ Although Citizenship teachers have basically been trained to teach their main subject areas (History, Geography, Economics, and Philosophy/Religion), they have not been trained specifically as teachers of Citizenship. Considering that training is an important component of becoming skilled and efficient and that effective teaching presupposes effective learning, it can be logically argued that the teaching of Citizenship started with a fundamental lapse of the absence of trained and qualified teachers. This problem needs an urgent attention.

\section{REFERENCES}

1. Anja, S.N. (2006). 'Management, Teaching Practice and Principles made simple'. Bamenda Cameroon. Patron Publishing House.

2. BameNsamenang.A.(2004).The 0 , TeachingLearning Transaction. An Africentric Approach to Educational Psychology. Bamenda Cameroon. HDRC Publications.

3. BameNsamenang. A. (2007), professionalism and ethics. A generative curriculum- Bamenda Cameroon HDRC Publications.

4. Cameroon (1998). Law No 004 of 14 April 1998 to lay down guidelines for the organization of education in Cameroon.

5. Cameroon (1998). Law No 004 of 14 April 1998 on the orientation of Education in Cameroon, especially as it concerns article 4, which emphasizes on the importance of moral and civics Education in the training of the citizens.
6. Carmen, P., Juauma, D., Paloma, D,.\& Ignacio, A. (2005). The Collaborative Development of Didactic Materials. Madrid, Spain.

7. Castling, A (1996). Competence - based Teaching Training London. Macmillan Press LTD.

8. Chris Culshaw, Jenny, Paul and Neil (2002). Citizenship Today. London. Harper Collins Publishers Limited.

9. Darlmg-Hammond,L.(2000).Teacher quality and student achievement. A review of state policy. Education policy analysis archives 8 (1) pp 1-45.

10. Darling- Hammond, L. (1999). Educating Teachers for the next century; Rethinking practice and policy in griffin.

11. David Keer.(1999). Citizenship Education; An International Comparism.

12. David Keer. Et al. (2007). Vision versus Pragmatism; Citizenship in the secondary school curriculum in England.

13. Dean, J. (1983). Organising learning in a primary school. British Journal of Education, 55, 127-128.

14. Derek Heater (2004). A brief History of Citizenship Nyu Press.

15. Derek Heater 2002. The Elements of Citizenship.

16. FelisaTobbits\& Judith Torney-Purta (1999), Citizenship Education in Latin America ;Preparing for the future.

17. Ferguson, R. \& Ladd, H.F.(1996). How and why money matters; An analysis of Alabama schools, in Ladd, H.F.(ed) Holding schools accountable (pp 265-298). Washington D. C ; Brookings Institute.

18. Ferguson, R.(1991). Paying for public education. New evidence on how and why money matters. Harvard Journal of Legislature, 28, 265 -298.

19. Geoff Petty.(2004). Teaching Today .3ed. Nelson Thornes Ltd.

20. Gokhan, O. \&Douglas,B- Clark. (2007). an overview of conceptual changetheories. Eurasia Journal of Mathematics, Science and Technology Education 3 (4), 351-361.

21. Iwu, Rosemary, Ijioma, Blessing, Onoja and Nzewoihe 2010.

22. Teaching Aids, a panacea for Effective Instructional Delivery in Biology. 
23. INCA (1 999). Meraational Review of Curriculum and Assessment Framework. 'Citizenship Education an International Comparism'.

24. Jesus, Rodriguez, R. (2002). Review and Analysis of research and initiatives on curricular materials on Honduras, Mexico.

25. Johnson, H.I. (1989) Relevant Instructional materials in family life education for Nigerian secondary schools.

26. Karla, Araya. A (2007) Teaching materials; A Critical position about the role they play in the language classroom.

27. K. Patricia Cross \& Thomas A. Angelo (1988); Classroom assessment techniques . A hand book for faculties.

28. Kennedy, K. (ED) 1997. Citizenship Education and the modern states. London Falmer press.

29. Keer, D. (1999.b) Changing the political culture; the advisory on education for citizenship and the teaching of democracy in schools. Oxford Review of Education. 25, 1\&2, 25-35. Knight, P. (1995) Assessmemt for learning in higher education. London Birmingham press.

30. Magda, Danciu, Marie Clake, AnnikaElm (2005). Citizenship Education in first cycle undergraduate teacher education courses. Maria Montessori (2011). Childhood Genius. Didactic materials for sensory education.

31. Mayer R. E and Moreno (1998). Cognitive Principles for multimedia Learning. Implications for design principles.

32. Mclaughlin, T. H (1992) ; Citizenship, diversity and education; a philosophical perspective; Journal of moral education, 21,3 ,235-246.
33. Morena R and Mayer R (1999). Cognitive Principles for multimedia Learning. The role of Modality and Contiguity. Journal of Education Psychology.

34. NECE. http;//www.neee.eu (Networking European Citizenship Education) 2010.

35. OgbondahLevinus. (2008). An appraisal of instructional materials used to educate migrant fishermen's children in River State Nigeria.

36. Organisation for Economic Cooperation and Development (O.E.C.D.1997).Education policy analysis Paris O.E.C.D.

37. Organisationof American States (O.A.S 1998) Unit for social development and education. Education in the Americas; Quality and Equity in the globalization process.

38. Peter, W. Airasian (1997) ;Classroom assessment. The McGraw-Hill companies Inc.

39. Pratt, D. (1994) Curriculum planning; A hand book for professionals. New York; Hacourt Brace.

40. Robin, F. (1999). How to raise test scores .U.S.A; Skylight training and publishing Inc.

41. Santrock (2004). Educational Psychology New York. McGraw Hill.

42. Seminar (2011). Seminar for Capacity Building of Social Science Teachers.pp 1-4, Buea Cameroon.

43. Simon, Ngwo, A. \&Fonche, P. (2001) Curriculum Processes, Concepts and Applications. The FONAP POLYTECHNIC PRESS. Bamenda Cameroon.

44. Sprinthall, N. A. and Sprinthall R.A (1990). Educational Pshychology. A Developmental Approach. McGraw Hill. Inc printed in the U.S.A. 